Primljen / Received: 10.7.2017.

Ispravljen / Corrected: 7.2.2018.

Prihvaćen / Accepted: 23.2.2018.

Dostupno online / Available online: 10.5.2018.

\section{Evaluation of groundwater contamination in former military airport area}

Authors:

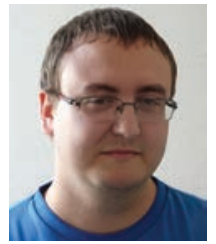

Lubomir Petrula, MCE

Brno University of Technology

petrula.l@fce.vutbr.cz

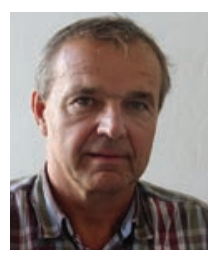

Prof. Jaromír Řiha, PhD. CE

Brno University of Technology

riha.j@fce.vutbr.cz

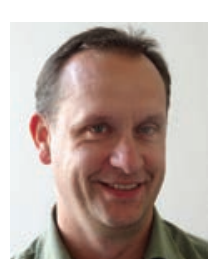

Assist.Prof. Tomáš Julínek, PhD. CE

Brno University of Technology

julinek.t@fce.vutbr.cz

\section{Lubomir Petrula, Jaromír Říha, Tomáš Julínek}

\section{Evaluation of groundwater contamination in former military airport area}

The analysis of groundwater contamination at the former military airport, due to fuel tanks leakage and other accidental spills, mainly involving polycyclic aromatic hydrocarbons (PAH), is presented in the paper. It was observed by modelling that, after termination of pumping, the contaminant by-passes the slurry wall around its edges and proceeds towards the withdrawal area. The modelling showed that the water contamination hazard is quite low, which is mainly due to pollutant deterioration (decay) and sorption.

Key words:
groundwater pollution, contaminant transport modelling, sorption, hydraulic barrier

Stručni rad

Lubomir Petrula, Jaromír Řiha, Tomáš Julínek

\section{Procjena onečiščenja podzemnih voda na području bivšeg vojnog aerodroma}

Rad se bavi analizom onečišćenja podzemnih voda na području bivšeg vojnog aerodroma uzrokovanog curenjem goriva iz spremnika te drugim slučajnim izlijevanjem onečišćivača, uglavnom policikličkih aromatskih ugljikovodika (PAH). Modeliranjem je zamijećeno da nakon prestanka crpljenja zagađivač zaobilazi brtveni zid oko njegovih rubova te se nastavlja kretati prema području gdje se zahvaća voda. Ovim modelom zaključeno je da postoji niska razina opasnosti od zagađenja, uglavnom zbog utjecaja raspada (razgradnje) zagađivača te sorpcije.

Ključne riječi:

onečiščenje podzemnih voda, modeliranje transporta zagadivača, sorpcija, hidraulična barijera

Fachbericht

Lubomir Petrula, Jaromir Říha, Tomáš Julínek

\section{Beurteilung der Grundwasserverschmutzung auf dem Gebiet des ehemaligen Militärflughafens}

Die Abhandlung befasst sich mit der Analyse der Grundwasserverschmutzung auf dem Gebiet des ehemaligen Militärflughafens, verursacht durch das Auslaufen von Treibstoff aus dem Tank sowie durch anderes zufälliges Auslaufen von Verschmutzern, hauptsächlich polyzyklischer aromatischer Kohlenwasserstoffe (PAK). Durch die Modellierung wurde beobachtet, dass der Verschmutzer nach Beendigung des Abpumpens die Dichtungswand um seine Ränder umgeht und seinen Weg zu dem Gebiet fortsetzt, wo das Wasser beeinflusst wird. Anhand dieses Modells kam man zu dem Schluss, dass die Gefahr der Verschmutzung hauptsächlich aufgrund des Einflusses der Zersetzung (Abbau) des Verschmutzers sowie der Sorption gering ist.

Schlüsselwörter:

Grundwasserverschmutzung, Modellierung des Transports der Verschmutzer, Sorption, hydraulische Barriere 


\section{Introduction}

There are many areas in which groundwater resources are threatened by groundwater pollution resulting from previous industrial, military and other activities. The pollutant transport to wider areas is governed by groundwater flow and by factors like dispersion, decay, sorption, etc. [1, 2]. Experiments involving inoculation of sandy porous media with microorganisms have been conducted. A biodegradation of pollutants and microorganism growth have been observed. Subsequent experiments have enabled determination of contaminant degradation parameters or influence of dissolved air [3, 4]. This paper focuses on the issue of solute transport. It mainly deals with modelling of the flow and transport of contaminants influenced by chemical reactions and adsorption. In addition, model validation has been conducted and several distinct scenarios have been solved.

\subsection{Area description}

The area of interest is situated in the Olomouc region of the Czech Republic. The groundwater withdrawal area is located to the southwest of a military airport (Figure 1). The water from this source is used as drinking water by nearby municipalities. In the 1970s several contaminant leaks were detected in groundwater samples [5]. Most of the contaminations were caused by leakage from underground fuel tanks and by accidental spills. To protect groundwater sources, a $0.6 \mathrm{~m}$ thick slurry wall was constructed with hydraulic conductivity of about $10^{-9} \mathrm{~m} / \mathrm{s}$, which makes it relatively impermeable with regard to the aquifer.

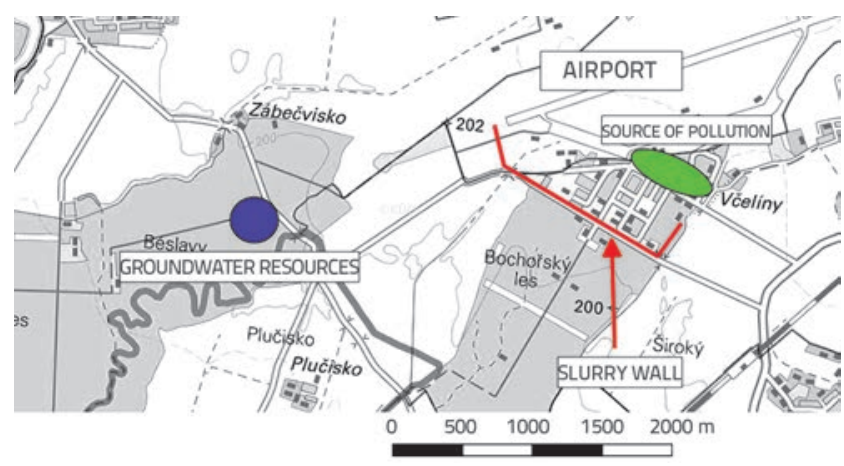

Figure 1. Map of the area of interest

Archival geological data from 14 boreholes were used to describe the porous media [6]. For practical purposes, the geological composition of the soil was generalized as follows:

- topsoil layer on the surface (mostly clays of low permeability, $\left.1.2 \cdot 10^{-9}-9.0 \cdot 10^{-5} \mathrm{~m} / \mathrm{s}\right)$,

- aquifer (sands, sandy gravels or gravels, high permeability, $\left.5.0 \cdot 10^{-4}-2.3 \cdot 10^{-3} \mathrm{~m} / \mathrm{s}\right)$.

The confining layer on the surface is approximately $2.5 \mathrm{~m}$ thick, while the aquifer is about $50 \mathrm{~m}$ in thickness.

\subsection{Pollution sources}

Contaminant leakage was recorded several times during service life of the airport. All pollution sources are shown in Figure 2. Analyses conducted in the area revealed the following contaminants [5]:

- hydrocarbons $\mathrm{C}_{10}-\mathrm{C}_{40^{\prime}}$

- benzene, toluene, ethylbenzene, xylene - BTEX

- methyl tert-butyl ether - MTBE.

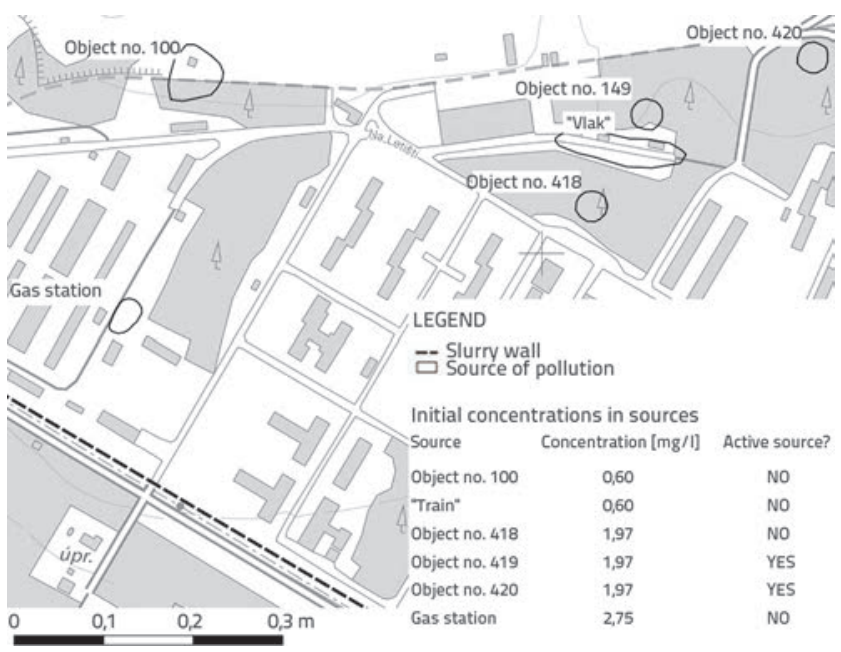

Figure 2. Map of contaminant sources

Some remediation and protection measures were performed in order to stop further contamination. These measures included construction of a slurry wall and pumping wells. According to [5], there are two structures from which the contaminant is actively transported. Furthermore, there are three structures that are inactive, but in which non-zero concentrations of the contaminant were observed. However, no "new" contaminant was introduced into the system from these locations. In this study, transport simulations were performed solely for hydrocarbons $\mathrm{C}_{10}-\mathrm{C}_{40}$.

\section{Methods}

A 3D numerical model was set up for the assessment. It consisted of two principal layers. The top layer represented relatively impervious and strongly contaminated topsoil, and the bottom one represented the aquifer. The numerical groundwater flow model was set up using the MODFLOW software with the MT3DMS module for pollution transport problem.

The problem and its solution consist of two parts. First, the groundwater flow model was set up and, subsequently, the contaminant transport module was applied.

\subsection{Groundwater flow}

In the first step, conceptual assumptions for groundwater flow modelling were taken into account. Subsequently, the modelled 
area was specified and boundary conditions (BC) were defined. Finally, the model calibration and verification was performed. After that, various flow scenarios were solved. The groundwater flow model is described as follows:

- convertible flow regime

- laminar and stationary flow

- model dimension: 3D

- homogeneous and isotropic.

The governing equation for groundwater flow is applied [1]:

$\frac{\partial}{\partial x_{i}}\left(k_{i} \cdot \frac{\partial H}{\partial x_{i}}\right)=Q_{D}$

where $x_{i}$ is the corresponding length in the coordinate system, $k_{i}$ is the hydraulic conductivity [m/s], $H$ is the water head [m], and $Q_{D}$ is a source $\left[\mathrm{m}^{3} / \mathrm{s}\right]$.

Boundary conditions must be defined to obtain the solution. The Dirichlet BC was applied to the boundaries of the model delineated along the surrounding rivers, [7]:

$\left.H(x, y, z)\right|_{\Gamma_{1}}=\bar{H}(x, y, z)[\mathrm{m}]$

where $H$ is the water head [m, m a. s. I.], $\bar{H}$ is the known water head $\left[\mathrm{m}, \mathrm{m}\right.$ a. s. I.] and $\Gamma_{1}$ is the boundary area. Water head values were adopted from [8], calculated, or estimated when necessary. The zero flow through the aquifer bed was governed by Neumann BC [7]:

$k_{i} \cdot \frac{\partial H}{\partial x_{i}} \cdot n_{i}=\left.q_{n}\right|_{\Gamma_{2}}=0[\mathrm{~m} / \mathrm{s}]$

where $n_{i}$ is the cosine of the outer normal to the boundary $\Gamma_{2}[-]$, $q_{n}$ is the flow rate $\left[\mathrm{m}^{2} / \mathrm{s}\right]$ i $\Gamma_{2}$ is the boundary area.

\subsection{Transport and chemical reactions}

The transport of oil products is theoretically a process in which two mutually immiscible substances are present in the porous media. Due to data availability issue, only the transport of hydrocarbons $C_{10}-C_{40}$ was simulated. Samples of these substances were taken, and laboratory tests were conducted. In the absence of additional information, it had to be assumed that these substances are dissolved in water. The transport process is essentially an unsteady one. The governing equation of transport, considering the advection, dispersion and chemical reactions, can be written as follows [1]:

$\frac{\partial c}{\partial t}=\frac{\partial}{\partial x_{i}}\left(D_{i j}^{H} \frac{\partial c}{\partial x_{j}}\right)-\frac{\partial}{\partial x_{i}}\left(v_{s, i} c\right)+q_{s} c_{s}+\sum R_{n}$

where $c$ is the concentration of the substance $\left[\mathrm{kg} / \mathrm{m}^{3}\right], c_{s}$ the concentration of the substance in the source $\left[\mathrm{kg} / \mathrm{m}^{3}\right]$, $t$ is the time [s], $D_{i j}^{H}$ is the hydrodynamic dispersion $\left[\mathrm{m}^{2} / \mathrm{s}\right], v_{s}$ is the velocity of water in pores $[\mathrm{m} / \mathrm{s}], q_{s}$ is the specific flow rate at source/sink [m/s] and $R_{n}$ are chemical reactions $\left[\mathrm{kg} / \mathrm{m}^{3} / \mathrm{s}\right]$. The change of concentration over time is expressed in Eq. (4). Factors defining transport of substance, i.e. advection, dispersion, sources and chemical reactions, are situated on the right hand side. The following chemical reactions were considered in the simulation:

- sorption

- decay.

The sorption describes the transfer of contaminant on the surface of grains of the porous medium. An equilibrium between the solute and the sorbed substance is assumed. A rapid reaction of the substance with the environment is considered as an instant constitutive change. A linear isotherm was used for the solution. A decay was described in the model using the $1^{\text {st }}$ order irreversible reactions. This process is defined as follows:

$-\left(\lambda_{1} n c+\lambda_{2} \rho_{b} c^{\prime}\right)\left[\mathrm{kg} / \mathrm{m}^{3} / \mathrm{s}\right]$

where $\lambda_{1}$ s the decay rate of solute $\left[\mathrm{s}^{-1}\right], \lambda_{2}$ is the decay rate of sorbed substance $\left[\mathrm{s}^{-1}\right], \rho_{b}$ is the bulk density $\left[\mathrm{kg} / \mathrm{m}^{3}\right]$ and $\mathrm{c}^{\prime}$ is the relative concentration of the substance sorbed [-]. The assumption that the decay rates $\lambda_{1}$ and $\lambda_{2}$ are equal is used in simulations. The sources of contaminant were defined as a set of Dirichlet BC:

$\left.c(x, y, z)\right|_{\Gamma_{3}}=\bar{c}(x, y, z)\left[\mathrm{kg} / \mathrm{m}^{3}\right]$

where $c$ is the concentration $\left[\mathrm{kg} / \mathrm{m}^{3}\right]$, and $\bar{c}$ is the known concentration $\left[\mathrm{kg} / \mathrm{m}^{3}\right]$. The initial condition is [7]:

$\left.c(x, y, z, t=0)\right|_{\Omega}=c_{0}(x, y, z)\left[\mathrm{kg} / \mathrm{m}^{3}\right]$

where $c_{0}$ is the concentration at the beginning of transport $\left[\mathrm{kg} / \mathrm{m}^{3}\right]$ and $\Omega$ is the modelled area. The initial condition was also used to describe residual contamination in structures that are no longer active (Figure 2).

\subsection{Model setup}

The modelled area was set up using the GMS software. Boundaries of the area are delineated by the streams Becva, Morava, and Mostenka (see Figure 3). The area was discretised into a regular rectangular grid $(10 \times 10 \mathrm{~m})$. Due to the geology in the area the model was composed of two layers: the confining layer on the surface, and the aquifer beneath it. The slurry wall was simulated using the horizontal flow barrier BC. Flow scenarios are divided into following groups:

- calibration (adopted from [8]),

- verification (adopted from [8]),

- new scenarios (derived from [5] and [8] or newly proposed).

New scenarios were defined by water stages on the borders of the area. The first scenario is set by water stages that 
correspond to the discharge lower than annual mean discharge $\left(Q_{a}\right)$. The third scenario was set by water stages near the 1 year flood return period. The second one lies between these two scenarios:

- WS1: low water stages $\left(\mathrm{Q}<\mathrm{Q}_{\mathrm{a}}\right)$,

- WS2: higher water stages (Q = 81.3 $\left.\mathrm{m}^{3} / \mathrm{s}, \mathrm{h}=2.20 \mathrm{~m}\right)$, - WS3: water stages near $\mathrm{Q}_{1}\left(\mathrm{Q}=190.6 \mathrm{~m}^{3} / \mathrm{s}, \mathrm{h}=3.20 \mathrm{~m}\right)$.

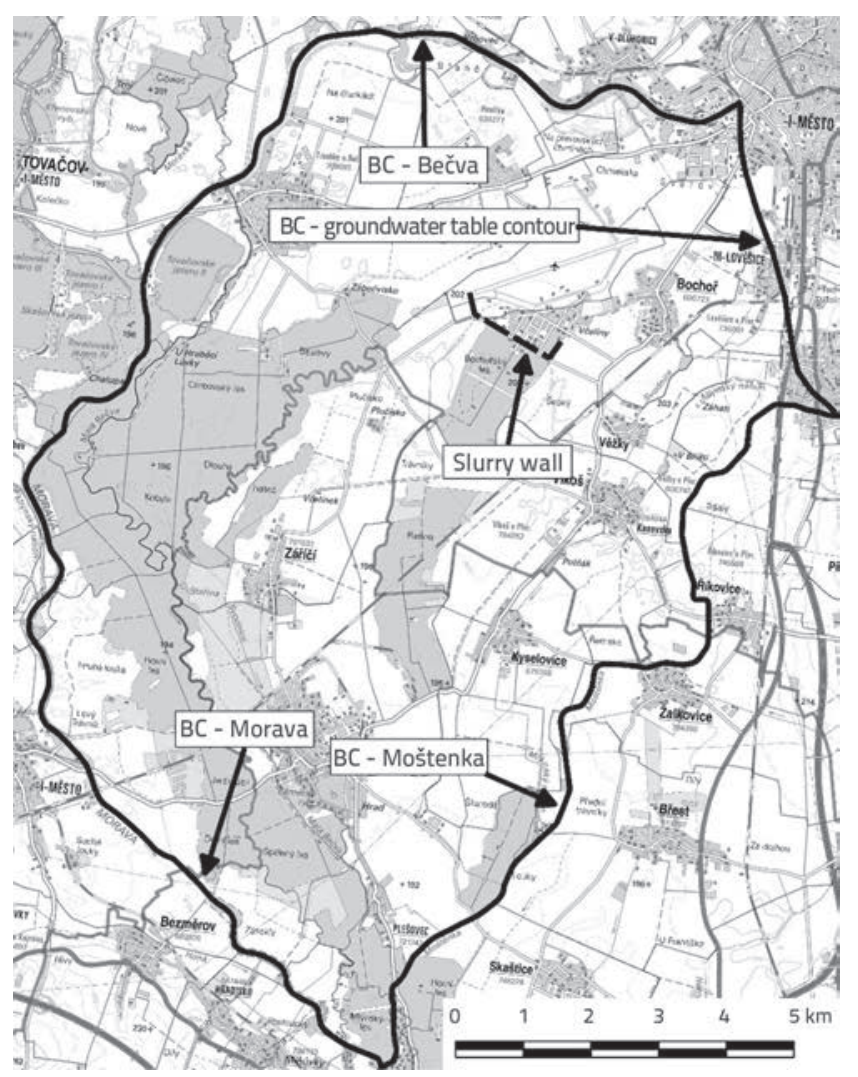

Figure 3. Modeled area and its boundaries

Two pumping scenarios were taken into account:

- SC1: maximum allowable pumping rate in the area,

- SC2: maximum allowable pumping rate except for wells near slurry wall

Six flow scenarios were set by combining water stages and pumping scenarios.

Transport of $\mathrm{C}_{10}-\mathrm{C}_{40}$ was modelled by using a calibrated groundwater flow model. The sources of contaminant are shown in Figure 2 . Concentrations of the $C_{10}-C_{40}$ were adopted from [5]. To define the model, the following variables had to be set [5]:

- porosity: top layer: 0.16

bottom layer: 0.12

- longitudinal dispersivity: $10 \mathrm{~m}$

- diffusion coefficient: $\quad 0.864 \mathrm{~m}^{2} /$ day

- bulk density: $\quad 1650 \mathrm{~kg} / \mathrm{m}^{3}$
A simplified scenario with no chemical reactions was solved to determine the simulation time. The result was that the contamination of groundwater in the withdrawal area was still observed after 25 to 30 years. Therefore, the total simulation time was set to 25 years. It was established that chemical reactions are an important factor of pollution transport in this area. As mentioned above, the sorption and decay were considered. The variants of distribution coefficients are given in Table 1.

Table 1. Variants of distribution coefficients

\begin{tabular}{|c|c|}
\hline Variant & Distribution coefficient $\left[\mathrm{m}^{3} / \mathrm{kg}\right]$ \\
\hline S1 & $1.34 \cdot 10^{-3}$ \\
\hline S2 & $1.95 \cdot 10^{-3}$ \\
\hline S3 & $3.90 \cdot 10^{-3}$ \\
\hline S4 & $8.23 \cdot 10^{-3}$ \\
\hline
\end{tabular}

The decay is defined by rate constants $\lambda_{1}=\lambda_{2}=0.092$ year $^{-1}$. The use of decay was marked by letter $\mathrm{D}$.

Five transport scenarios can be defined (either with sorption only or with decay only). Then, by combining sorption and decay, another four scenarios were defined: $S 1+D, S 2+D, S 3+D$ and S4+D. So, nine transport scenarios were applied to each flow scenario. In total, 54 simulations with chemical reactions were solved.

\subsection{Calibration and verification}

A scenario of water stages, based on data from [8], and the corresponding water table isolines, were used for model calibration. The pumping in the area was not considered. The calibration was carried out for the state before slurry wall construction. As mentioned above, the entire region consists of two layers (confining layer on the top and aquifer). For calibration purposes, the area was divided into macroelements. A hydraulic conductivity was then assigned as constant over each macroelement. The convergence to measured values [8] was achieved by changing hydraulic conductivities. Firstly, rough estimates of hydraulic conductivities were found using the trial-and-error procedure, which was followed by optimization in the PEST module of the MODFLOW software. The final comparison of water head isolines is shown in Figure 4. After calibration, the model accuracy was verified using different water level scenario taken from [8].

The calibration of transport model was not carried out due to the lack of data. Simulation results were compared only qualitatively with older models [5]. In addition, numerous simulations were carried out to quantify sensitivity of results with respect to various input variables. 


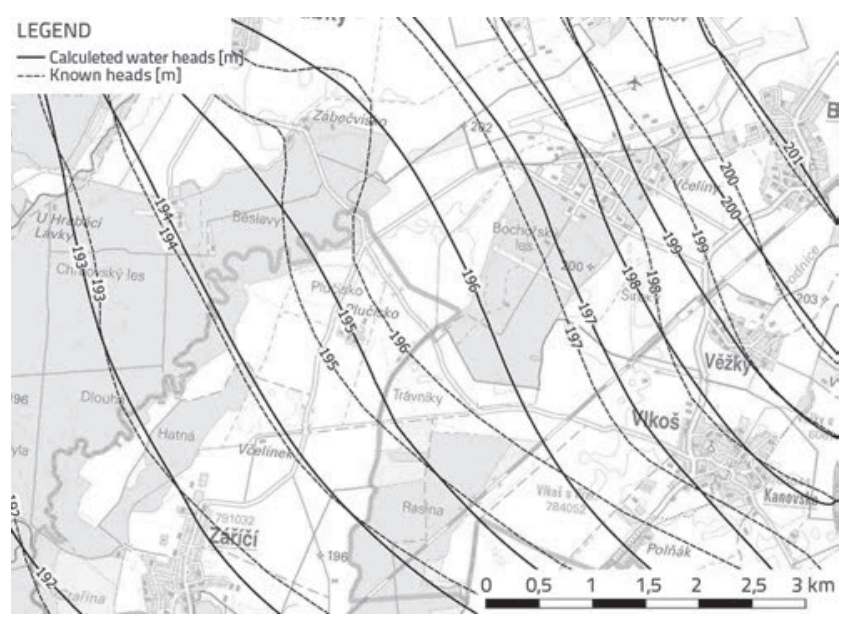

Figure 4. Final comparison of water head isolines

\section{Results and discussion}

\subsection{Groundwater flow}

An example of calculated piezometric heads (contour lines) for the scenario WS1+SC1 is shown in Figure 5.

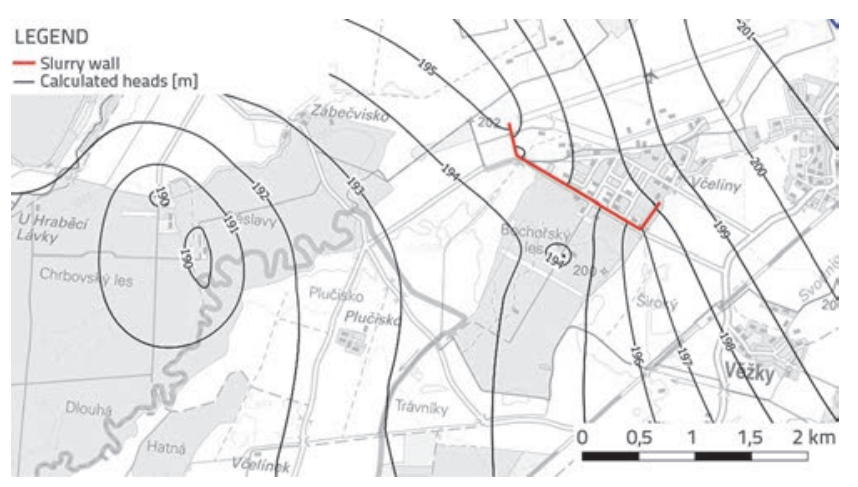

Figure 5. Example of calculated water heads, WS1+SC1

It can be seen that the slurry wall acts as a relatively impermeable structure. In case of an active hydraulic barrier, the pumping wells would trap all pollution coming from the airport. In case of deactivated pumping, it may be expected that contaminant would propagate around the slurry wall edges and then towards the withdrawal area.

\subsection{Results - transport of $C_{10}-C_{40}$}

Theoretically, the worst possible scenario is the one in which the hydraulic barrier is disabled and the chemical reactions are not taken into account. In this case, the model indicated that the contamination would reach the water withdrawal area in about 25 years. However, this critical and conservative assumption is far from reality. Therefore, the following simulations focused on the effect of constitutive changes and chemical reactions that probably play a significant role in this case. As to the type of constitutive change, the simulations were divided into two categories:

Simulations with decay only: It was established that the solution of these simulations does not practically depend on the groundwater flow scenario selected. The results rather depend on the scenario of the pumping at the barrier and at the withdrawal area. An example of this simulation in case of deactivated hydraulic barrier is shown in Figure 6. As expected, the contaminant was transported around the edge of the slurry wall. In some places, the contaminant penetrated through the wall (as discussed in Section 3.3). In scenarios with active pumping near the wall, the transport towards the slurry wall (or even beyond it) was observed, and the pollution was trapped via pumped wells.

Simulations with both sorption and decay: Results of these simulations do not depend on water stages nor on the pumping scenario. This is because of the dominant influence of the sorption and decay, which results in a relatively rapid immobilization of contaminant. The pumping at the slurry wall is rather insignificant as the decay rate surpasses the rate of flow so that practically no pollution reaches the pumping wells. Therefore, the results depend only on specification of distribution coefficient. An example of such result is shown in Figure 7. The resulting transport distances were in the order of hundreds of meters (see Table 2). This result contradicts the groundwater pollution monitoring carried out at the wells at the barrier where practically no pollution has been identified for the last several years.

One of the objectives of this study was to assess whether contamination of the withdrawal area is possible. Further on, the results were assessed in terms of transport distance of concentration $0.10 \mathrm{mg} / \mathrm{l}, 0.50 \mathrm{mg} / \mathrm{l}$ and lateral spread of the contaminant. The resulting values are summarized in Table 2.

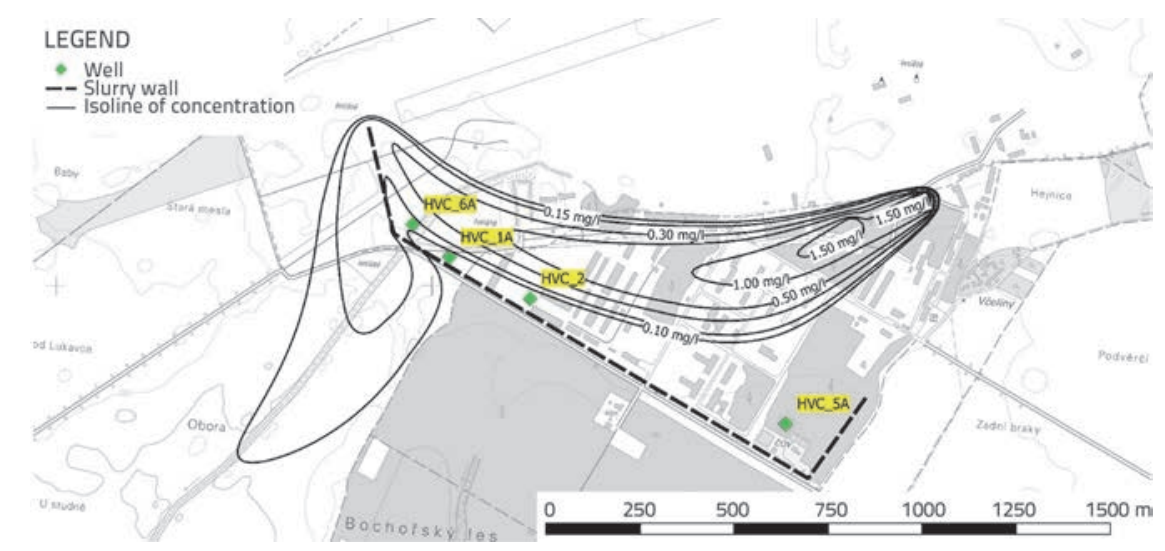

Figure 6. Concentrations of $\mathrm{C}_{10}-\mathrm{C}_{40}$; hydraulic barrier disabled (SC2); chemical reactions: $\mathrm{D}$; $t=\mathbf{2 5}$ years 


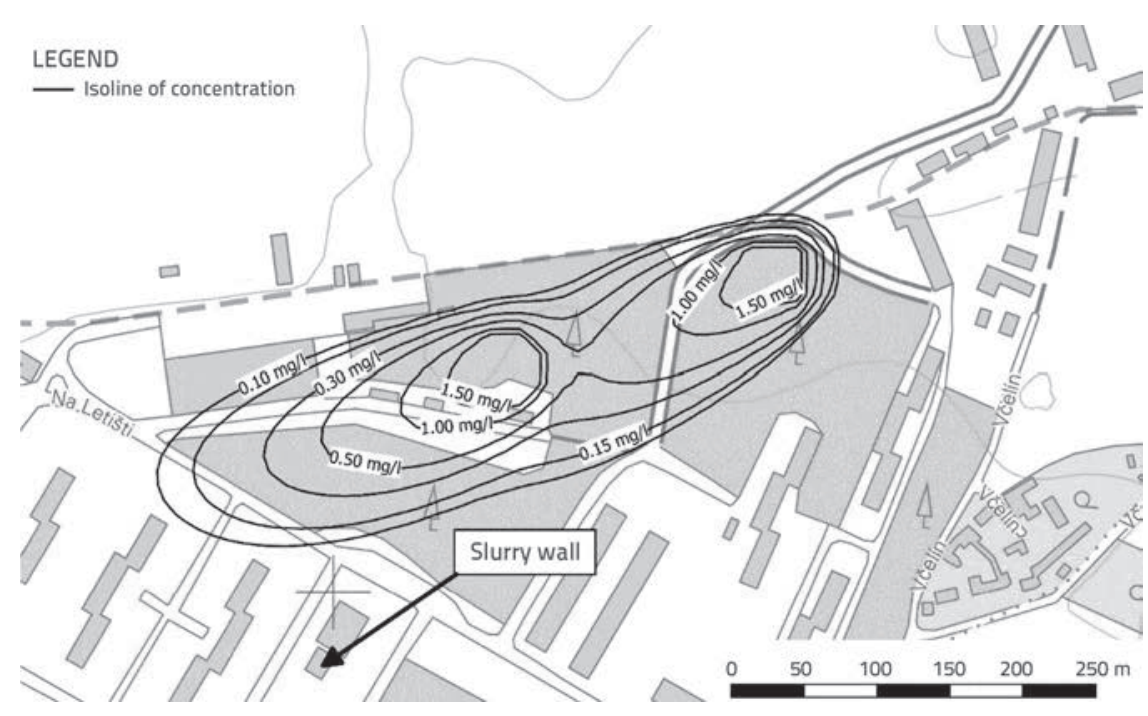

Figure 7. Concentrations of $C_{10}-C_{40}$; hydraulic barrier disabled; chemical reactions: $S 1+D$; $t=25$ years

Table 2. Monitored transport values; $t=25$ years

\begin{tabular}{|c|c|c|c|}
\hline $\begin{array}{c}\text { Simulaction } \\
\text { variant }\end{array}$ & $\begin{array}{c}\text { Transport distance of } \\
\boldsymbol{c = 0 . 5 0} \mathbf{m g} / \mathbf{I} \\
{[\mathrm{m}]}\end{array}$ & $\begin{array}{c}\text { Transport distance of } \\
\boldsymbol{c = 0 . 1 0} \mathbf{m g} / \mathbf{I} \\
{[\mathrm{m}]}\end{array}$ & $\begin{array}{c}\text { Lateral } \\
\text { spread } \\
{[\mathrm{m}]}\end{array}$ \\
\hline SC1 - D & 950 & 1340 & 990 \\
\hline SC2 - D & 1100 & 2530 & 280 \\
\hline SC2 - S1 - D & 150 & 450 & 140 \\
\hline SC2 - S2 - D & 115 & 400 & 110 \\
\hline SC2 - S3 - D & 75 & 325 & 100 \\
\hline SC2 - S2 - D & 55 & 90 & 90 \\
\hline
\end{tabular}

It is clear that a higher distribution coefficient leads to lower transport distances and spreading.

\subsection{Discussion}

One of the problems encountered during the study was the model calibration. The calibration data were adopted from [8]. This reference, however, is only an interpretation of older and time inconsistent data. In addition, the pumping data for the area are not specified for this scenario. For more precise calibration a new field data would be required.

The results showed only minor influence of pumping scenario at the withdrawal area and the groundwater flow conditions. Simulation results are more influenced by the parameters of sorption and decay processes.

Another issue was definition of the slurry wall. This could be done properly only in terms of groundwater flow. In terms of transport, it would be preferable to model the slurry wall using the true material it is made of. If the material of the wall is a mixture of clay and cement, it is likely that it would have completely different parameters in terms of transport (porosity, dispersivity).
However, the specification of transportrelated properties and parameters is hardly possible. The consequence during the modelling is that the contaminant was transported through the slurry wall by the dispersion effect even if there is practically no flow through the wall. However due to the conservatively chosen input variables, the results of the simulations tend to be on the safe side.

Yet another factor is the application of chemical reactions. In [5] several soil samples were taken and analysed to acquire the distribution coefficient and decay rate. The values applied in the simulation correspond to the average value of the values identified in [5].

\section{Conclusion}

The numerical model assuming no constitutive changes indicated that, after termination of pumping, the contaminant might bypass the slurry wall around its edges, and proceed towards the withdrawal area, which would be reached in approximately 25 years. Further study was focused on testing the effect of constitutive changes which represent more realistic scenarios. The model indicates that contaminant transport in the airport is strongly influenced by chemical reactions that take place in the porous media. In their absence, the withdrawal area would be contaminated within several decades. When the reactions are taken into account, the contaminant would not reach the withdrawal area even if the pumping from the hydraulic barrier is terminated. It was also found that even when a minimal distribution coefficient is applied in the model, the contaminant would be immobilized already within the airport area. The withdrawal area has not been threatened in any simulated scenarios. Based on the modelling results, the following final recommendations can be formulated:

- establish systematic, reliable and long-term groundwater quality monitoring,

- the hydraulic barrier near the slurry wall may be disabled,

- make a cost analysis to compare expenses for elimination of pollution sources and impact of contamination on the aquifer,

- make a detailed analysis of distribution coefficients and decay rates throughout the affected area to improve reliability of simulations,

- create a local transport model (3D) at the slurry wall area and make a more accurate sensitivity analysis in terms of decay and sorption. 


\section{Acknowledgements}

This paper was prepared in the scope of the projects No. L01408 AdMaS UP - Advanced Materials, Structures and Technologies, and FAST-S-16-3655 Tools for risk assessment of surface water quality under extreme hydrological situations. The authors would also like to thank the Czech Geological Survey and VaK Prerov for the provision of valuable data.

\section{REFERENCES}

[1] Bear, J., Verruijt, A.: Modeliranje tokova podzemnih voda zagađenja: s računalnim programima za primjere, Kluwer Academic Publishers, Norwell, MA, U.S.A., 1987, ISBN 9781556080159.

[2] Wood, B., Dawson, C., Szecsody, J., Streile, G.: Modeliranje transporta i razgradnje zagađivača u slojevitim poroznim medijima, Water Resources Research, 30 (1994) 6, pp. 18331846.

[3] Javadi, A., AL-Najjar, M.: Modeliranje transporta zagađivača u tlu uključujući učinak kemijskih reakcija metodom konačnih elementa, Journal of Hazardous Materials, 143 (2007) 3, pp. 690-701.

[4] Simmons, C., Fenstermaker, T., Sharp Jr., J.: Tok podzemnih voda promjenjive gustoć i tansport otopljene tvari u heterogenim poroznim medijima: pristupi, rješenja i budući izazovi, Journal of Contaminant Hydrology, 52 (2001) 1-4, pp. 245275.
[5] LOM PRAHA s.p. Dopuna obnovljenoj analizi rizika Přerov aerodroma. Prag, 2015.

[6] Češka geološki agencija [online]. Dostupno na: http://www. geology.cz/extranet/.

[7] Duchan, D., Říha, J., Zachoval, Z.: Hidraulični aspekti infiltracije oborinskih voda: hidraulika infiltracije oborinskih voda, Tehnološko sveučilište Brno, Građevinski fakultet, Brno, 2014, ISBN 9788021450172.

[8] Kouřil, Z.: Podzemna voda u dolini rijeke Morave, Institut za geografiju ČSAV, Studia geographica, Brno, 1970. 